- Communication-

\title{
Electrical Conductivity and Density of Cryolite-Base Melts
}

\author{
Katsuhisa ITOH* $^{*}$ and Eiji NAKAMURA
}

Received February 9, 1993 ; Accepted March 23, 1993

\section{INTRODUCTION}

Cryolite-base, $\mathrm{Na}_{3} \mathrm{AlF}_{6}-\mathrm{AlF}_{3}-\mathrm{CaF}_{2}$ melts are wellknown solvents for alumina and have been the major components of electrolytes for the production of aluminium. The electrical conductivity and density of a cryolite-base melt have long been both of theoretical interest and practical significance. Although a number of measured values of these properties for binary and ternary melts are available ${ }^{1-4)}$, data vary considerably and reliable ones are scarce, mainly because of the corrosive nature of the pertinent melts and the frequency dispersion of the measured conductivity. For industrially important quarternary melts, previous conductivity measurements are moreover scarce $3,5-7$ ).

In the laboratory measurements of resistivity (the inverse of conductivity) of the quarternary melts, Caspard et al.5) once reported that the resistivity of a bath containing 6 mass\% (designated as $\%$ hereafter) $\mathrm{CaF}_{2}$ showed an abnormal decrease at ca. $6 \%$ $\mathrm{Al}_{2} \mathrm{O}_{3}$ and the decrease became maximum with the bath containing $6 \% \mathrm{AlF}_{3}$. They inferred a change of the melt structure with the anomaly. They could not observe, however, the anomaly in the industrial pots.

Our objects are to obtain frequency-independent, reliable conductivity data for industrial standard baths and to reinvestigate the above-mentioned anomaly with the help of measurements of density which also has a strong relationship with the melt structure.

\section{EXPERIMENTAL}

Reagent-grade chemicals were used. Measuring samples were premelted. The compositions of solvent baths were varied as follows: $\mathrm{AlF}_{3}, 3 \%, 6 \%$, and $9 \%$; $\mathrm{CaF}_{2}, 3 \%$, and $6 \%$; and $\mathrm{Na}_{3} A \mid F_{6}$, the remainder. The $\mathrm{Al}_{2} \mathrm{O}_{3}$ contents of measuring samples were varied within $0-8 \%$ by 0.5 or $1 \%$ increments.

The apparatus employed for conductivity measurements using a platinum conductivity cell similar to the one reported by Bajcsy et al.8) is illustrated in our previous abstract ${ }^{6}$ ). We used, however, a

New Metal Products Development Department, Technical Research Laboratories. Sumitomo Light Metal Ind., Ltd. (1-12, 3-chome, Chitose. Minato-ku, Nagoya 455) Key Words: Electrical conductivity, Density, Cryolite-base melts, Anomaly in conductivity platinum hemispherical electrode as a container for a melt in place of a separate crucible as described earlier by $\mathrm{Fay}^{9}$ ). A platinized-platinum rod with a hemispherical lower end was immersed as the other electrode into the melt.

The ac bridge used was the Kelvin bridge (Shima$\mathrm{dzu}$, Type $\mathrm{BF}-902)$. A sinusoidal wave $(1-50 \mathrm{kHz})$ was applied to the bridge with an oscillator (HewlettPackard, Type 204C), and bridge balance was obtained with a tuned null detector (Yokokawa/HewlettPackard, Type 4403 A). The conductivity measurements were carried out typically at $1273 \mathrm{~K}$.

Using the platinum black on the rod electrode for each run and balancing the reactance of a measuring melt with a variable capacitance connected to the standard resistance of the bridge first enabled us to virtually eliminate the frequency-dependence of the measured resistance at frequencies over $7 \mathrm{kHz}$. We regarded the measured resistance for these frequency range as polarization resistance-free, i.e., as purely ohmic, whereas most of the previous reports employed some extrapolation procedures 1,4 ), which is one of the major sources of error, to obtain the resistance at infinite frequency. By the use of the double hridge, we were able to measure a small resistance of the cell, such as less than 0.2 $\Omega$, excluding a much larger lead resistance.

The cell constants were obtained at ambient temperatures at six precise immersion depths of the rod electrode with standard aqueous $\mathrm{KCl}$ solutions. Equation (1), first developed by Fay ${ }^{9}$ ), has been established between these cell constants, $K_{\text {cell }}$, and the measured values of the resistance, $R$, of the melt at the corresponding immersion depths,

$$
R=\rho K_{\text {cell }}+R_{\text {lead }}
$$

where, $\rho$ is the resistivity of the melt, and $R_{\text {lead }}$, the lead resistance (substantially zero in our case). From the slope of Eq. (1), we can obtain the resistivity, $\rho$.

The validity of this treatment has been confirmed with preliminary measurements for some melts including pure cryolite, for which a commonly accepted literature value was reported 3,4 ).

The densities were measured at a series of temperatures by the hydrostatic weighing method using a platinum sinker as described previous $\left.1 y^{10}\right)$. 


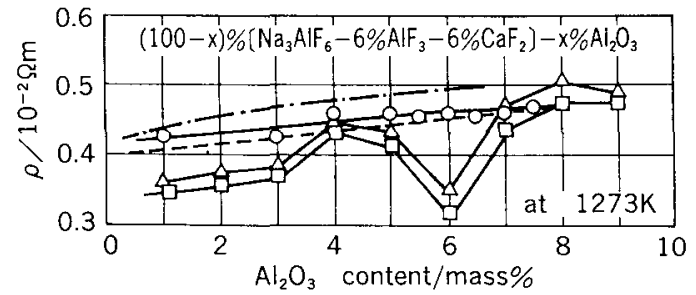

Fig. 1 Dependence of resistivity of $\left[\mathrm{Na}_{3} A \mid \mathrm{F}_{6}-6 \%\right.$ $\left.\mathrm{AlF}_{3}-6 \% \mathrm{CaF}_{2}\right]-\mathrm{Al}_{2} \mathrm{O}_{3}$ melts on $\mathrm{Al}_{2} \mathrm{O}_{3}$ content.

-0 - : This work. $\triangle$ : Gaspard et al.5) (at $1263 \mathrm{~K}$ ). $-\square$ : Caspard et al.5)(at $1283 \mathrm{~K}$ ). - - - : Vidament and Rey cited in ref. 3 (solv.: $6 \% \mathrm{AlF}_{3}-5 \% \mathrm{CaF}_{2}$ at liquidus temp.).-- -: Fell ner et al.'s reg.eq. 12).

\section{RESULTS AND DISCUSSION}

Figure 1 shows the dependence of our measured values of the resistivity on the $\mathrm{Al}_{2} \mathrm{O}_{3}$ content in the bath, in which Gaspard et a1.5) observed the most abnormal decrease. In Fig. 1 we also show relevant literature data 3,5$)$ and calculated values with the regression equation first derived by Choudharyl1) and later modified by Fellner et al.12) for the conductivity as a function of both composition and temperature from reliable data. All the curves in Fig. 1, except for Gaspard et al.'s, show no abnormal changes around $6 \% \mathrm{Al}_{2} 0_{3}$. Our resistivity data (not shown) obtained in the $3 \% \mathrm{AlF}_{3}-6 \% \mathrm{CaF}_{2}$ solvent bath, in which Gaspard et al, also observed a slightly abnormal change, show no anomaly.

Figure 2 shows our resistivity data for two solvent baths both containing $3 \% \mathrm{CaF}_{2}$. In these melts again we observe no anomalies. Our data in Fig. 2 agree well with those calculated with the regression equation of Fellner et al.

Figure 3 shows the dependence of our density data of related melts on the $\mathrm{Al}_{2} \mathrm{O}_{3}$ content at $1273 \mathrm{~K}$, together with typical literature datal,2) for the $\mathrm{Na}_{3} \mathrm{AlF}_{6}-\mathrm{Al}_{2} \mathrm{O}_{3}$ melt. All the plots in Fig. 3 , and the other plots (not shown) obtained by us at different temperatures, and of literature data for pertinent

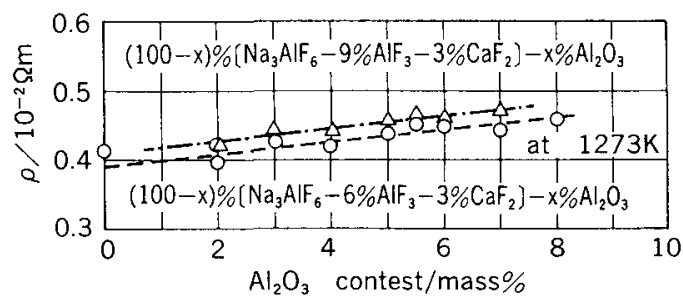

Fig. 2 Dependence of resistivity of $\left[\mathrm{Na}_{3} \mathrm{AlF}_{6}-\mathrm{AlF}_{3}-\right.$ 3\% $\left.\mathrm{CaF}_{2}\right]-\mathrm{Al}_{2} \mathrm{O}_{3}$ melts on $\mathrm{Al}_{2} \mathrm{O}_{3}$ content.

$\mathrm{O}$ : This work (solv.: $6 \% \mathrm{AlF}_{3}-3 \% \mathrm{CaF}_{2}$ ). $\triangle$ : This work (solv.: $9 \% \mathrm{AlF}_{3}-3 \% \mathrm{CaF}_{2}$ ).-- - Fellner et al.'s reg. eq. 12) (solv.: 6\% $\mathrm{AlF}_{3}-3 \% \mathrm{CaF}_{2}$ ).-.- FelIner et al.'s reg. eq. ${ }^{12}$ ) (solv.: $9 \% \mathrm{AlF}_{3}-3 \% \mathrm{CaF}_{2}$ ).

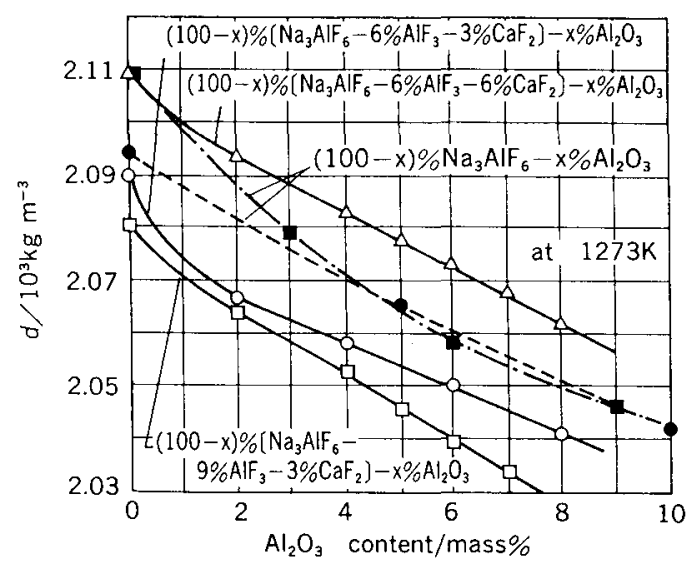

Fig. 3 Dependence of density of $\mathrm{Na}_{3} \mathrm{AlF}_{6}-\mathrm{A} 1 \mathrm{~F}_{3}-\mathrm{CaF}_{2}$ $\mathrm{Al}_{2} \mathrm{O}_{3}$ and $\mathrm{Na}_{3} \mathrm{AlF}_{6}-\mathrm{Al}_{2} \mathrm{O}_{3}$ melts on $\mathrm{Al}_{2} \mathrm{O}_{3}$ content.

-O-: This work (solv.: 6\% AlF $3-3 \% \mathrm{CaF}_{2}$ ). $-\widehat{\triangle}$ : This work (solv.: 6\% $\mathrm{AlF}_{3}-6 \%\left(\mathrm{CaF}_{2}\right.$ ). $-\square$-: This work (solv.: 9\% $\mathrm{AlF}_{3}-3 \% \mathrm{CaF}_{2}$ ). - - Edwards et al.1)

-. -.: Matiašovský and Mal inovsk(s2).

melts demonstrate a nearly 1 inear relationship, around $6 \% \mathrm{Al}_{2} \mathrm{O}_{3}$, with the $\mathrm{Al}_{2} \mathrm{O}_{3}$ content, which seems to deny the change, near $6 \% \mathrm{Al}_{2} 0_{3}$, of the melt structure or the change of the species of the complex ions generally bel ieved to be formed.

In conclusion, the present results resolve the anomaly reported in the previous work 5 ) for the baths near the industrial standard compositions and confirm the tendency predicted from the previous regression equations, al though melt structure even when $\mathrm{Al}_{2}{ }^{0} 3$ is added to $\mathrm{Na}_{3} \mathrm{AlF}_{6}$ is not yet well established. The data obtained by Gaspard et al.5) in the industrial pots and those by Wang et al.7) in the laboratory also support the conclusion.

\section{REFERENCES}

1) J. D. Edwards, C.S. Taylor, L. A. Cosgrove and A.S. Russell, J. Electrochen. Soc., 100, 508 (1953).

2) K. Matiašovskf and M. Malinovsky, Electrochim. Acta, 11, 1035 (1966).

3) M. Rolin. Electrochim. Acta, 17, 2293 (1972) and ref. 23 cited therein.

4) P. Fellner, O. Kobbeltvedt. \&. Sterten and J. Thonstad, Electrochim. Acta. 38, 589 (1993).

5) J.R.Gaspard, J.Goret and M. Ferber, Light Metals 1975. Vol. 1, TMS-AIME, New York, p. 79 (1975).

6) K. Itoh and E. Nakamura, 10th Symposium of the Molten Salt Committee of the Electrochemical Society of Japan, Abstr. A207 (1976).

7) X. Wang. R.D. Peterson and A.T. Tabereaux, Light Metals 1992, TMS, New York, p. 481 (1992).

8) J.Bajcsy. M. Malinovsky and K. Matiasovsky, Electrochim. Acta, 7, $543(1962)$

9) H. Fay, J.Phys. Chem., 70, 890 (1966).

10) N. Tanaka, K. Hukuoka, and K. I toh, Sumitomo Light Metal Tech. Rep., 16, 102 (1975).

11) G. Choudhary, J.Electrohem. Soc., 120, 381 (1973).

12) P. Fellner, K. Grjotheim and H. Kvande, J.Met., 37 No. $11,29(1985)$. 